\title{
Perspective
}

Expert insights on a timely policy issue

\section{Whither Hong Kong?}

\author{
Andrew Scobell, Min Gong
}

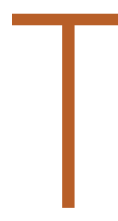

he dominant narrative about China since the 1970s has been one of unprecedented economic growth under the watchful eye of a reform-minded communist party. While the spotlight has focused on the seemingly unstoppable

Chinese juggernaut, scant attention has been paid to the small former British colony of Hong Kong off China's southern coast. If a compelling side story surfaced, it was Taiwan: During the 1990s, the island witnessed the emergence of a raucous democracy and the expansion of economic and people-to-people links across the Taiwan Strait.

In contrast, developments in Hong Kong seemed humdrum. However, events since 2014 have raised the territory's profile and prompted questions about its future. How has the relationship between the two entities evolved over time? What is the territory's significance to China today? What is Hong Kong's future trajectory? Hong Kong continues to be of considerable economic and political value to Beijing and remains a bellwether of trends and policies inside the People's Republic of China (PRC), particularly toward territories it claims as sovereign.
Over the past seven decades, Hong Kong has thrived as its economy has transformed from a regional hub for light industrial manufacturing into a major global financial center. Liberal economic policies made this transformation possible: Today, Hong Kong is one of the world's most unfettered economies when mea-

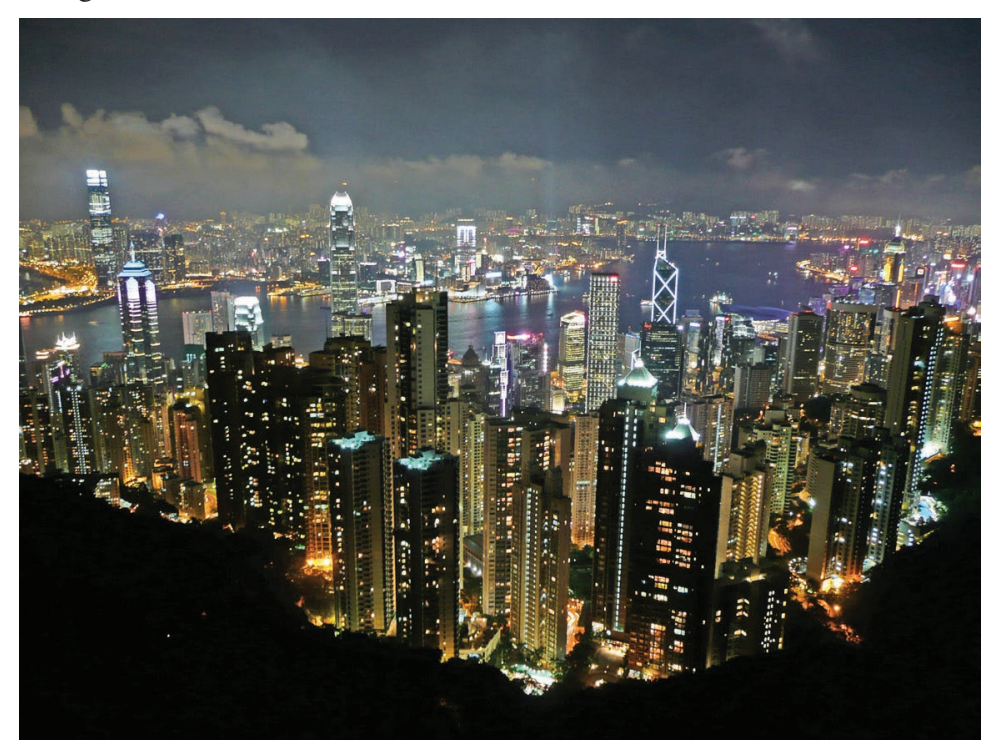

Photo by bsterling via Flickr (CC BY-SA 2.0) 
sured on the basis of its regulatory efficiency, adherence to rule of law, and absence of restrictions on the flow of capital, goods, and services. ${ }^{1}$

The city of seven million is a Special Administrative Region (SAR) of the PRC, which means that China and other countries and international organizations treat it as a distinct economic and administrative entity. In negotiations with London two decades prior to the 1997 handover, known in Chinese as "the return" (huigui), Beijing promised to grant Hong Kong a high degree of political and economic autonomy until at least 2047. Although the SAR would remain subordinate to the PRC on matters of foreign affairs and defense, it would receive eventual universal suffrage in government elections in return. These principles are enshrined in two high-profile documents: the Sino-British Joint Declaration of 1984 and the Hong Kong Basic Law passed by China's legislature, the National People's Congress (NPC), in 1990.

At midnight on June 30, 1997, the Union Jack - the red, white, and blue flag of the United Kingdom - was lowered for the last time, and the wuxinghongqi-the scarlet five-starred banner of the PRC — was raised, signaling the start of a new era for Hong Kong. The relatively smooth-but not flawless-transfer of sovereignty was testament to the firm commitment of Beijing and London to the territory's continued prosperity and Hong Kong residents' confidence in the future. The absence of any economic turbulence was noteworthy and stood in stark contrast to the economic upheaval in 1982 that accompanied the announcement that the world's then-second most powerful communist state wanted to take control of the small capitalist enclave. Nevertheless, some observers doubted how well Hong Kong would function after 1997.

\section{While doubts have long been expressed about Hong Kong's post-1997 fate, there has never been any question about the high level of importance Beijing attaches to the status of the city.}

One respected social science study concluded that the territory's future under PRC sovereignty was "bleak." ${ }^{2}$

\section{Big Trouble in Little Hong Kong?}

While doubts have long been expressed about Hong Kong's post1997 fate, there has never been any question about the high level of importance Beijing attaches to the status of the city. Indeed, PRC leaders clearly consider Hong Kong as a "core interest," on a par with other highly sensitive sovereignty issues such as Taiwan, Tibet, and Xinjiang. ${ }^{3}$

This Perspective considers the future trajectory of the SAR in light of the 2014 prodemocracy street protests and their aftermath. First, it examines economic and political trends in Hong Kong-China relations; second, it considers the issues triggering these protests; third, it considers the effect of the protests; fourth, it explores possible future scenarios; and lastly, it offers some concluding observations.

\section{Trends in Hong Kong-China Relations}

Since China's leader Deng Xiaoping launched the remarkably successful post-Mao economic reforms in the late 1970s, two key trends have characterized Hong Kong's relationship with China. 


\section{First, Hong Kong has become far less important to China} in absolute economic terms, but the two entities are gradually developing an integrated economy, and Hong Kong remains key to China's international trade and investment.

Hong Kong has long loomed large for the PRC, particularly since the late 1970s. As China sought to open itself to foreign investment and trade, the then-British colony played a crucial role as the country's main economic gateway: first for the marketing of Chinese goods and then as a source of capital. Previous research has identified four factors that fueled increased Hong Kong-sourced foreign direct investment (FDI) in China: China's export-promotion FDI strategy, China's large pool of cheap labor, Hong Kong's specific advantages in export-oriented FDI, and Hong Kong's unique links with China. ${ }^{4}$ Between 1979 and 1995, almost 60 percent of FDI pouring into China either originated in or was funneled through this global financial center. ${ }^{5}$ At the same time, Hong Kong was the most important port through which Chinese exports were transshipped to the rest of the world.

Moreover, since 1979, mainland cities have been transformed through a process that one of the authors of this paper has dubbed "Hong Kongization." Apparently, following the Hong Kong model of dense urban growth, China's major cities came to look more

\section{While the size of Hong Kong's economy} relative to China's has shrunk as a result of the far more rapid growth of China's economy, the two economies have also become more interconnected and interdependent since the handover. and more like Hong Kong-providing health care, education, and economic opportunities to closely packed residents living in an amalgam of impressive-looking skyscrapers and intricate transportation systems, including sprawling subways, elevated expressways, and showpiece airports.

As the mainland locales that were permitted to accept FDI gradually proliferated, spreading northward and inland from the initial four Special Economic Zones in Guangdong Province (Shenzhen, the most successful, was established directly adjacent to the then-British territory) and Fujian Province, Hong Kong's role as an economic gateway to China became less important. Moreover, other Chinese cities_ — such as Guangzhou, Tianjin, and Shanghai-dramatically upgraded and expanded their port facilities, making China far less dependent on Hong Kong.

But Hong Kong has become more important as the global hub for China's offshore Renminbi (RMB) activities. Beijing has embraced RMB internationalization as part of its long-term strategy to establish a steady global currency market. The central government hopes that RMB internationalization will help China avert currency attacks, avoid exchange rate risk, reduce transaction cost, obtain foreign financing at lower cost, as well as increase its global political power. One key step of RMB internationalization is to ensure a robust offshore RMB market, and Hong Kong currently fills this role admirably as well as providing a bridge "linking the onshore RMB market with the offshore market."

While the size of Hong Kong's economy relative to China's has shrunk as a result of the far more rapid growth of China's economy, the two economies have also become more interconnected and interdependent since the handover. Figure 1 shows the changes in the Hong Kong-China economic relationship during this period. 
Figure 1. Hong Kong-China Economic Relationship Compared: 1997 Versus 2014

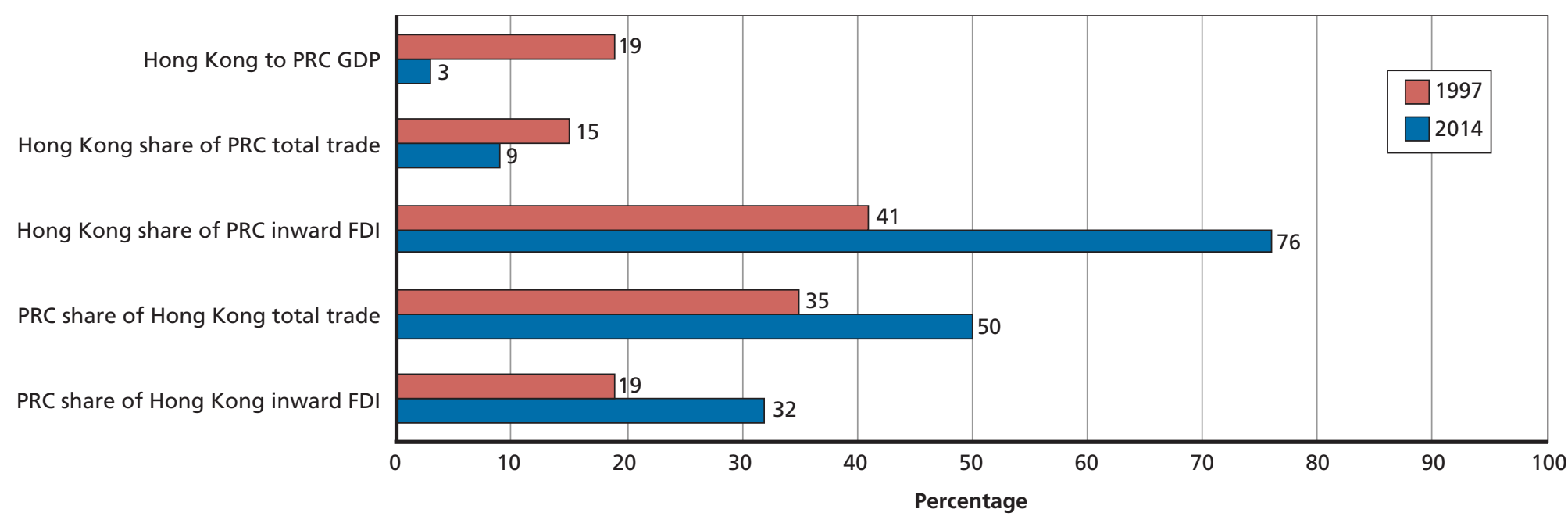

SOURCES: Trade and Industry Department of Hong Kong SAR; Comprehensive Department, Ministry of Commerce of PRC; China Statistical Yearbooks; United Nations Conference on Trade and Development; China share of Hong Kong inward foreign direct investment data were from 2013. NOTE: GDP = gross domestic product.

RAND PE203-1

Although the absolute ratio of Hong Kong's GDP compared with China's GDP has dropped from 19 percent in 1997 to 3 percent in 2014 as a result of continuous levels of high economic growth on the mainland, Hong Kong remains critical to China's economy. The SAR is China's second largest foreign trade partner (9 percent of China's total trade in 2014 was with Hong Kong) and its largest source of foreign direct investment (roughly 75 percent of China's FDI came from Hong Kong in 2014). ${ }^{8}$ Given the Chinese economy's heavy dependence on external demand, these figures suggest that Hong Kong is playing an increasingly important, if different, role in China's economic development and growth today than in the past.
China, meanwhile, has become far more important to Hong Kong, accounting for fully half of the territory's total trade and almost one-third of Hong Kong's inbound FDI in 2014. ${ }^{9}$ Since the 2004 implementation of the Closer Economic Partnership Agreement (CEPA) - a comprehensive free-trade agreement between the two entities-Hong Kong's GDP growth has been boosted by an estimated 4 percent annually. ${ }^{10}$ The goods that many Hong Kong trading companies buy and sell are manufactured in China.

Hong Kong attracts millions of tourists each year; while most tourists of past decades came from Japan and other parts of Asia (and beyond), the vast majority of tourists now come from the mainland. Chinese visitors to Hong Kong come for the pleasures of 
high-end duty-free shopping, gambling on racehorses, and exploring the Disneyland and Ocean Park theme parks. This influx of mainland tourists has accelerated since the implementation of the Individual Visitors Scheme in 2003, whereby Chinese citizens from selected mainland cities are no longer required to visit Hong Kong in tour groups. However, since 2014, the flow of tourists from China to Hong Kong has decreased. In 2014, the number of mainland tourists who visited Hong Kong was roughly 4.2 million. In 2015, it was roughly 3.5 million, registering a 15.5 percent drop. ${ }^{11}$

\section{Second, although Hong Kong has lost its status as a crucial} economic intermediary between China and Taiwan, it has acquired great political importance as a concrete symbol of national unification.

For Beijing, Hong Kong served for decades as an important transshipment hub with Taiwan and a key node for cross-Strait transportation. Commerce between China and Taiwan was funneled through Hong Kong until then-Taiwan President Ma Yingjeou approved direct trade in 2008. Likewise, all cross-Strait air travel was routed through Hong Kong until direct flights between the island and mainland were approved in 2008.

After the 1997 transformation from British colony to PRC SAR, Hong Kong became the first tangible achievement of Beijing's national unification project. The "one country, two systems" policy proposal became a reality as post-1997 Hong Kong retained its own currency, free market economy, and a high degree of autonomy. This included making good on Beijing's assurance that "Hong Kong people would rule Hong Kong": local career civil servants continued to run the territory, and the top administrator-with the title of "chief executive" — was chosen by a progressively expanded election committee composed of prominent Hong Kong residents.
In the colonial era, the most senior leader was the "governor," who was appointed by London without any consultation with the people of Hong Kong. But Beijing was careful to ensure that proestablishment figures dominated the post-1997 political scene.

China held up the SAR as proof that it was sincere in its promise to offer Taiwan an even better deal: reunification under the same "one country, two systems" approach but with even greater autonomy, including permission for Taiwan to retain its own armed forces. For Taipei, the Hong Kong experiment became a useful bellwether of the political climate on the mainland. Indeed, Hong Kong and Taiwan are both painfully aware that, under Chinese Communist Party (CCP) leadership, the mainland has at times been roiled by economic upheaval and political mayhem. The Great Leap Forward in the late 1950s and early 1960s caused the most severe economic devastation and produced mass starvation, while the Cultural Revolution in the late 1960s and early 1970s unleashed the most serious political chaos. Although the PRC political system has become much less volatile and far more institutionalized over the course of the post-Mao era, the tragedy of 1989 is a reminder that the potential for turmoil remains.

However, until recent years, Beijing has largely abided by its commitments following the handover. Hong Kong has continued to have a separate status from the rest of China, and the boundary between the SAR and neighboring Guangdong Province essentially functions as an international border, with access to Hong Kong restricted to legal Hong Kong residents or those PRC residents with approval to visit. Hong Kong has maintained its pre-1997 legal system, grounded in British common law, but the final court of appeal is now located in Hong Kong itself instead of at the Privy Council in London (although the power of final interpretation of legislation 
is vested in the NPC Standing Committee in Beijing). Indeed, the rule of law is still a fundamental principle in the territory, and the people of Hong Kong enjoy freedoms not experienced by citizens in the rest of China. A number of organizations considered subversive by Beijing and banned on the mainland operate legally and openly in the SAR, including the Falun Gong spiritual movement and the Roman Catholic Church. ${ }^{12}$ Moreover, Hong Kong remains one of only two locations in the PRC where annual rallies are permitted to commemorate the Tiananmen Square massacre of June 1989 (the other is the nearby Macao SAR). ${ }^{13}$ Just as importantly, dissidents who would likely be silenced on the mainland have been tolerated in Hong Kong. For example, Han Dongfang, a prominent leader of the 1989 demonstrations, is permitted to work as a labor activist in Hong Kong and even to broadcast a radio show into the mainland. However, over time, there has been a gradual erosion of civil liberties, and the political climate in the SAR has become increasingly tense. Particularly shocking were the cases of several dissident publishers who mysteriously disappeared in late 2015 only to suddenly reappear on the mainland, making what appeared to be staged confessions to crimes they allegedly committed. ${ }^{14}$

Furthermore, at critical junctures, Beijing has proved responsive to political realities in Hong Kong, backpedaling in the face of adverse reactions to political initiatives directed at the SAR. In 2003, for example, with the backing of the mainland government, the Hong Kong government attempted to introduce a harsh antisubversion law — the National Security Bill—pursuant to Article 23 of the Basic Law but withdrew in the face of strong popular protests in the territory. Then, in 2011, and again with backing from Beijing, the Hong Kong government tried to introduce a mandatory patriotic education curriculum into local schools. When there was widespread public opposition, Beijing and the Hong Kong government again backed down, with the latter announcing that adoption of this curriculum would be optional.

\section{The Trigger and the Aftermath}

On the issue of selecting the process by which the SAR's chief executive would be chosen, Beijing has not appeared to be in any mood to compromise or backpedal. An August 2014 announcement from China's NPC that placed limitations on the implementation of universal suffrage in Hong Kong's 2017 chief executive elections triggered protests. While the announcement stated that the people of Hong Kong-for the first time-would be able to vote for their chief executive in a popular election, it required that candidates running for the position receive preapproval from a nominating committee handpicked by Beijing before they could list their names on the ballot. However, such action was mandated by the 1990 Basic Law, and the people of Hong Kong were well aware that a decision about the format and procedures for future elections of the chief executive was forthcoming.

Indeed, starting in 2013, there was an intense debate about the composition of the nominating committee and what would be a tolerable process for the selection of the SAR's top political leader. This debate involved a wide range of groups in the territory, including political moderates and various members of Hong Kong's Legislative Council (LegCo). According to one well-informed analyst, by the spring of 2014, a compromise solution was possible, but Beijing balked. ${ }^{15}$ When the PRC showed no flexibility, local democrats responded by standing firm.

This announcement triggered prodemocracy street demonstrations that gripped Hong Kong for 79 days in late 2014, highlight- 
ing the fact that some Hong Kong residents continue to harbor substantial concerns about the political and economic future of this vibrant Asia-Pacific metropolis. While the scale of these protests in terms of absolute numbers was modest compared with political demonstrations in other countries (such as those in Egypt in 2011), on a per capita basis, the numbers were significant. It is estimated that more than one million Hong Kong residents out of a total population of some seven million demonstrated at some point. Moreover, the protesters in Hong Kong were young, impassioned, and representative of wider underlying societal disaffection in the Chinese territory. The protests evolved into a broad popular movement dubbed the "Umbrella Movement" lasting from late September to mid-December $2014 .{ }^{16}$ But there is still dissatisfaction two years later, even after June 2015, when LegCo voted down the Beijing-sponsored proposal to revamp the procedure for selecting the territory's chief executive that triggered the street protests.

The SAR's LegCo put the proposal to a vote in mid-June 2015, resulting in its defeat by an overwhelming margin because the democrats in a strong show of solidarity all voted against the measure while a large bloc of pro-Beijing members vacated the legislative chamber and were absent for the actual vote. Although the result should not have surprised anyone, since passage required a two-thirds majority vote, the scale of the defeat probably came as a shock to Beijing. ${ }^{17}$ The outcome underscored the level of popular disaffection in the SAR and the divisions within Hong Kong society. The schism in the legislature appeared to mirror the existence of a major societal divide between those who supported the proposal-many likely adhered to the Cantonese slogan of doizyusin ("pocket it for now"), believing that the proposal was the best deal Hong Kong could get from Beijing under the circumstances-and those who passionately opposed it, believing that the proposed electoral arrangement would merely set the stage for sham elections of Hong Kong's chief executive in 2017 and beyond. ${ }^{18}$

\section{A Dilemma for Beijing}

Beijing will likely find it extremely difficult to placate Hong Kong's grassroots opposition movement. The 2014 protestors were a coalition of diverse groups, including the "Occupy Central with Peace and Love" movement, launched in September 2014 by a university law professor, and "Scholarism," originally established by secondary-school students three years earlier to oppose the patriotic education curriculum Beijing sought to impose upon the territory. Among the demonstrators' demands was the resignation of unpopular Chief Executive Leung Chun-ying, whose five-year term of office does not end until 2017. ${ }^{19}$

These demonstrations had considerable support among students in secondary schools and universities, according to many independent observers. ${ }^{20}$ Hong Kong residents have long been assumed to be politically apathetic and materialistic. But the 2014 movements remind observers that local people possess deep feelings of civic pride-feelings that were manifest on such earlier occasions as annual commemorations of the 1989 Tiananmen massacreand underscored the sense that the SAR's citizens possess a separate and distinct identity from their kin who live on the mainland. ${ }^{22}$ Widening income inequality, limited career prospects, and high housing costs have alienated Hong Kong youth. Young people tend to blame most or all of these problems on an influx of mainlanders to the territory in the post- 1997 period. ${ }^{23}$ There has been a lively prodemocracy movement in Hong Kong for decades, but until recently, it appeared to be largely limited to a group of aging intel- 
lectual activists such as septuagenarian lawyer Martin Lee. Now, new generations have emerged, personified by middle-aged activists such as Benny Tai and younger campaigners such as Joshua Wong. Moreover, the movement has spread across generations and to the middle class, gauging from the results of the September 2016 LegCo elections, and enjoys considerable and continuing grassroots support. ${ }^{24}$

Moreover, the continued political disaffection in Hong Kong poses a real dilemma for Beijing. On the one hand, China's communist rulers continue to view meeting the demands of political activists or compromising with liberal members of the SAR's legislature as unacceptable options. ${ }^{25}$ Such actions could carry intolerable costs for the regime by emboldening disenfranchised groups on the mainland to take to the streets in pursuit of greater democracy, regional autonomy, or other causes. On the other hand, a harsh crackdown in the SAR could likely have adverse outcomes on the peaceful progress of China's unification project. Although Hong Kong matters less economically to the mainland today than it did a decade or two ago, some economic effect remains likely, especially if there are spillover effects on capital allocation or trade decisions made in other foreign capitals. If extended street protests reappear, they could further damage the territory's economy while slowly eroding the political capital China has built up through the success of its unification project. Were the disaffection to escalate into mass violence either because of intrasocietal tensions in the SAR or as a result of brutal repression, then the outcome could be even more severe for Hong Kong and China. The rioting on the

\section{The continued political disaffection in Hong}

Kong poses a real dilemma for Beijing.

\section{The Umbrella Movement has had some measurable short-term effect on Hong Kong's economy; the longer-term implications are more speculative but potentially very significant.}

night of February 8-9, 2016-the so-called fish ball protests—in Mongkok District suggests not only lingering public disaffection but also hints at the continued potential for more sustained and larger protests. ${ }^{26}$

\section{Impact of 2014 Protests}

The Umbrella Movement has had some measurable short-term effect on Hong Kong's economy; the longer-term implications are more speculative but potentially very significant.

Short-Term Passing Storm. In the short term, the protests had limited effect on the Hong Kong economy. Although officials from both mainland China and Hong Kong warned at an early stage that the protests could bring economic disaster for Hong Kong, data show that the protests had little effect on the SAR's economy. Hong Kong's stock market, tourism, labor market, and property sectors all remain strong, although there has been a modest weakening in retail sales as well as in the flow of tourism. Hong Kong's Hang Seng Index (HSI) dropped 3.2 percent after the police used tear gas, but it quickly bounced back to the preprotest level and beyond. The Morgan Stanley Capital International (MSCI) Hong Kong Index rallied 6.7 percent in October 2014_the highest percentage gain among all developed markets tracked by MSCI- 
compared with a 0.6 percent gain in the MSCI World Index in that month. The stock link between Hong Kong and Shanghai took effect on November 17, 2014, after a brief delay in late October partially caused by the protest, according to the chief executive officer of Hong Kong's stock exchange. The Hong Kong economy also grew 2.7 percent year on year in real terms in the third quarter of 2014, a surprising increase from the 1.8-percent growth in the second quarter. In 2014, Hong Kong's economy grew by 2.5 percent year on year in real terms.

The luxury retail sales sector was hit hardest by the protest. The peak of the protests coincided with the National Day Golden Week (October 1-7), which typically has generated 40 percent to 60 percent of October retail sales because of the influx of mainland shoppers. According to the Hong Kong Retail Management Association, most retailers reported sales declines ranging from 15 percent to 50 percent, compared with the Golden Week of 2013. But the retail section was already experiencing negative growth before the protests, mainly because of the Chinese economic slowdown and President Xi Jinping's anticorruption drive. Tourism remained strong during the Golden Week, with a 4.8-percent increase in tourist arrivals, according to the Hong Kong Tourism Board. A drop in average spending offset the growth in the tourist arrivals, however. Protests may have contributed to the spending decrease, as people shifted away from traditional high-spending shopping areas affected by the protests. The results were even worse during 2015's Golden Week. According to a survey released by the Hong Kong Retail Management Association, retail sales dropped by close to 40 percent compared with $2014 .^{27}$ While the 2015 retail-sales decline cannot be conclusively attributed to the protests, it seems likely that they are linked: The 15.5-percent drop-off in mainland tourists visiting Hong Kong in 2015 (noted above), which certainly adversely affected retail sales, is probably the result of potential visitors' perception that the territory was less welcoming.

In the "Third Quarter Economic Report 2014," the Hong Kong government warned that the protests "caused disruptions to economic activities in such sectors as retail, catering and inbound tourism, with their negative effects on the local consumption market and the economy as a whole likely to show up successively in economic data in the coming months." 28 This gloomy forecast was quickly rendered moot by subsequent events.

Long-Term Impact. Fundamentally, what is at stake in Hong Kong is business confidence - a fragile and potentially volatile sentiment in any economy. The 2014 protests did not appear to have seriously affected business confidence. The consequences of increased and sustained meddling by Beijing in the territory would be far more dire. If business confidence plummets, triggering capital flight or a stock market crash, the economic consequences for China and the region would be considerable. ${ }^{29}$ These consequences would have political costs, too: Many of Beijing's closest allies in Hong Kong are members of the business elite-the very people who would have the most to lose in the event of a serious economic downturn in the territory.

Such an economic disaster in Hong Kong would probably be viewed as ending any realistic hope of peaceful unification with Taiwan for the foreseeable future, so Chinese leaders have a lot riding on Hong Kong's continued success. Beijing is loathe to see economic catastrophe for another reason: It could have dire implications for the fate of China's leaders. There is a strong belief that the events in Hong Kong include political embarrassment for the CCP. It would be the ultimate ignominy were Hong Kong to expe- 
rience an economic meltdown after just a few decades on Beijing's watch, since London administered the territory for some 150 years and produced a modern, vibrant city in robust economic health. PRC leaders are prone to perceive any turmoil or unrest in Hong Kong as having been instigated or at least orchestrated by "foreign forces" intent on undermining CCP rule and dividing China. As a result, senior Chinese leaders view this situation through a lens of heightened insecurity and sensitivity rather than recognizing that their policies toward Hong Kong have created this popular resentment. Similarly, Chinese leaders perceived the peaceful popular mainland protests of 1989, which began in Beijing and spread to cities across China, as a socially destabilizing movement supported by behind-the-scenes, overseas-based conspirators - and ultimately as a threat to the regime. Beijing viewed the 2014 Hong Kong protests as equally insidious. This concern over foreign meddling is heightened by the extended history of British links to the territory and repeated U.S. expressions of attentiveness toward Hong Kong. Reinforcing the latter is the Hong Kong Act, passed by the U.S. Congress in 1992, which articulates Washington's abiding interest in monitoring human rights and democratic development in the territory following the 1997 handover (but the legislation does not mandate any U.S. government action). In November 2014, when President Barack Obama met President Xi Jinping in Beijing at the Asia-Pacific Economic Cooperation summit, the U.S. leader emphasized that the ongoing street protests in Hong Kong were the manifestation of genuine popular frustration with local problems rather than the result of any interference by Washington.

\section{The Political Path Ahead: Continued Freedom Without Democracy?}

Hong Kong residents have long enjoyed considerable freedom of personal action and political expression. This was the case in the pre-1997 era and has remained largely so until recent years. Such civil liberties as freedom of expression and freedom of the press are well-established traditions in Hong Kong, although these freedoms have noticeably eroded since 1997. But Hong Kong residents have never enjoyed full democracy, either under British rule or under PRC administration. ${ }^{30}$ Nevertheless, for many decades, Hong Kong people have had very modest and quite limited opportunities to vote, mostly in grassroots elections at the neighborhood and district levels. ${ }^{31}$ Some scholars who study democracies have identified political systems that they label "hybrid regimes." ${ }^{2}$ By this, they mean that sometimes it is not completely accurate to classify a polity in dichotomous terms as either a "democracy" or a "dictatorship.” Some countries, such as Vladimir Putin's Russia, may have regular elections, but few objective analysts would say these are the result of free and fair voting. Moreover, some self-proclaimed democracies, such as Singapore, may have many characteristics of a democratic system, including regular elections and rule of law, but at the same time make it very difficult for opposition candidates and parties to contest elections and place significant limitations on civil rights.

If we conceive of Hong Kong in such hybrid terms, we are then able to analyze the current political environment and explore a range of possible future political trajectories for the SAR. Moreover, it is useful to conceive of a hybrid polity as possessing two main dimensions: political freedoms themselves and the actual mechan- 
ics of elections. Each of these variables can vary across a spectrum depending on how fettered or unfettered the system is at any point in time. Using these two variables - freedom and democracy-this Perspective envisions four possible political outcomes for Hong Kong in the coming decade: the status quo, repression, democratic opening, or ritualized democracy with less freedom (see Figure 2). Some scenarios are much more plausible than others, so this Perspective discusses and assesses each in terms of its likelihood on the following scale: most likely, likely, unlikely, and most unlikely.

\section{Status Quo Ante (Freedom Without Democracy): Most Likely} The political system more or less returns to the pre-2014 Umbrella Movement situation. This appears to be what is happening. In June 2015, Hong Kong's LegCo rejected the electoral reform proposal, and the result was a return to the status quo prior to the demonstrations. Hong Kong people will continue to enjoy considerable personal and political freedom-but not democratic enhancement. The 2014 protests petered out in the face of firm intransigence by authorities in Beijing and Hong Kong. It is possible-albeit unlikely_that Beijing may yet make a gesture to accommodate some demands - just as it has in the past_- while essentially maintaining the status quo ante in the territory. However, the 2017 selection of the chief executive will proceed under existing rules, and Hong Kong's political system appears destined to remain largely unchanged for the foreseeable future. A return to the status quo ante does not mean that political protests will be absent. Prodemocracy activists may well conclude that while democracy for Hong Kong is probably unattainable, periodic street demonstrations and other forms of nonviolent activism may be most impor-

\section{Figure 2. Possible Political Outcomes for Hong Kong}

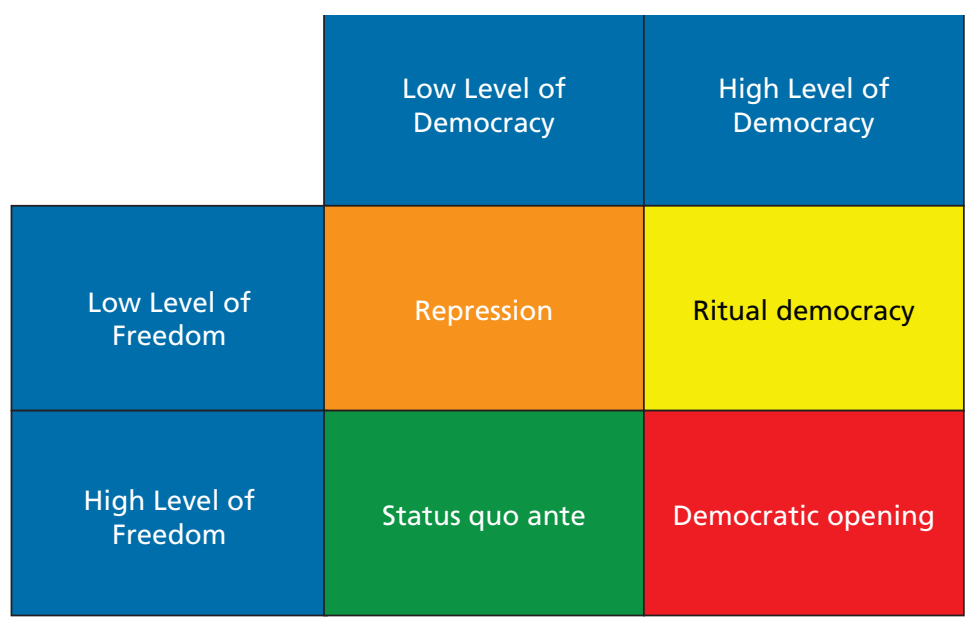

NOTE: Color indicates likelihood, with green indicating the most likely scenario and red indicating the least likely scenario. RAND PE203-2

tant in sustaining the high level of freedom enjoyed by Hong Kong residents into the future.

\section{Ritual Democracy (Procedural Democracy and a Loss of Freedom): Likely}

Beijing turns Hong Kong into a version of the rest of China. The outcome would be one in which people could vote only for approved candidates, and personal freedoms are eroded gradually and consistently. Procedurally, Hong Kong people might exercise the right to vote, but the act of voting would be politically meaningless. This outcome appears to be possible, but less likely than a preservation of the status quo. It would require a greater willingness by Beijing to intervene and could occur if Chinese leaders became 
more concerned about discontent in Hong Kong. Efforts since 2014 to mute media outlets and muzzle critics of Beijing's policies in the SAR are alarming and suggest that China may already be working to achieve this outcome by intimidating activists into submission. ${ }^{33}$ Such an eventuality might be viewed as a more palatable and reasonable option than a harsh crackdown (see the third scenario,

"Repression"). Beijing might try to reintroduce some variant of its 2014 proposal for the selection of the chief executive in a manner it believes might be less objectionable to Hong Kong people—or Beijing might try to simply railroad the proposal through at some point.

\section{Repression (Neither Freedom nor Democracy): Unlikely}

A political crackdown could lead to political repression and a rollback of the rule of law in Hong Kong. However, even if street protests resume in the territory, the specter of a Tiananmen Square-like crackdown is a remote possibility. The People's Liberation Army (PLA) garrison is "invisible" in the sense that it maintains an extremely low profile-rarely venturing out of its barracks and often conducting training exercises outside of Hong Kong. ${ }^{34}$ Moreover, the Hong Kong Police are very professional, well trained, and highly capable of dealing with a broad range of scenarios from mass demonstrations, widespread civil disobedience, and more severe disturbances, including riots. ${ }^{35}$ This outcome could emerge if new protests occurred and escalated into serious violence or if widespread unrest erupted in the territory and Beijing responded in muscular fashion. Of course, more subtle forms of repression can have the desired effects, but these are less visible and/or confrontational. In recent years, a proindependence movement has emerged in Hong Kong. This is remarkable on a number of levels, notably

\section{Beijing turns Hong Kong into a version of the rest of China. The outcome would be one in which people could vote only for approved candidates, and personal freedoms are eroded gradually and consistently.}

because it seems to be an unattainable quest and because it is illegal to advocate separatism for any part of the PRC, including Hong Kong. Thus, anyone openly advocating independence for the territory is subject to legal prosecution and political persecution. ${ }^{36}$

\section{Opening (Freedom with Democracy): Most Unlikely}

Beijing reverses itself and accedes to popular pressure, permitting direct universal suffrage in elections for Hong Kong's chief executive. This outcome is extremely unlikely because of its implications for internal stability and regime survival on the mainland. This outcome would require a sea change in Beijing's thinking-something that, although possible, is highly unlikely. This scenario seems inconceivable at least during the expected tenure of President Xi Jinping — until the 2022-2023 time frame.

\section{Concluding Discussion}

Hong Kong's future political-economic trajectory is far from clear and is largely dependent on the interactive dynamics between Beijing and the people of Hong Kong. Chinese leaders are likely to respond cautiously to conditions, as they are reluctant to undermine business confidence. A harsh crackdown or high-profile intervention by Beijing beyond what has occurred to date to alter the status quo in Hong Kong in a way that could undermine the 
rule of law is improbable except under extreme circumstances, since China's rulers would fear the adverse effect on business confidence. Moreover, events in Hong Kong could easily produce tensions in China's relations with Taiwan, the United Kingdom, and the United States, since each of these polities has significant economic investments in Hong Kong and sizable numbers of citizens living in the territory. For example, according to the U.S. Department of State, 60,000 Americans call the SAR home and some 1,400 U.S. companies maintain offices in Hong Kong. Moreover, in 2014, the United States conducted some $\$ 47$ billion in two-way trade with the SAR (worth only about 8 percent of the volume of U.S.-PRC two-way trade, but still significant). Meanwhile, U.S. FDI in Hong Kong is almost $\$ 59$ billion, which is even higher than the amount of FDI the United States has in the rest of the PRC. ${ }^{37}$ Beyond economics, a harsh response from Beijing would also invite international condemnation. At the same time, it would signal to both Washington and Taipei how willing Beijing is to use force to complete its unification project.

This Perspective has laid out a range of possibilities for Hong Kong's future and argued that China has a substantial stake in the territory's outcome. The risks to Beijing include damage to China's international reputation, derailment of its unification project, and adverse effects on the Chinese economy. Moreover, a bad outcome in Hong Kong would almost certainly send shock waves through domestic Chinese politics, likely raising questions about Xi Jinping's judgment and directly affecting Chinese political leaders, many of whom have investments_-or children working or studying-in Hong Kong.

The most likely outcome, however, is not catastrophe but a return to something approaching the political status quo ante in
Hong Kong. But it is still too early to tell whether this will be the case. The authorities waited the demonstrators out, and the 2014 protests eventually wound down, only to be rekindled periodically. Meanwhile, the method of selecting the SAR's chief executive remains unchanged following the mid-2015 legislative veto. While the effect of the protests on Hong Kong's own economy has been limited, any decline in retail sales may have multiplier effects on its GDP. However, other political actions and decisions by Beijing are likely to have far greater effects on Hong Kong's economy. Indeed, political and economic trends on the mainland will have considerable influence on Hong Kong. Moreover, it is unclear what the effect of mega projects pushed by China, such as the ZhuhaiMacau-Hong Kong Bridge across the Pearl River Delta, will be on the SAR.

Regardless of Hong Kong's precise trajectory, the protests and their aftermath have heightened Beijing's sensitivity to threats from domestic dissent in the territory and elsewhere in China. Beijing is more likely to adopt a tougher response to any future protests in Hong Kong. Although political activism in the territory may subside in the short term, it is unlikely to disappear completely, absent improved career prospects for Hong Kong youth. But the vast majority of Hong Kong residents are pragmatic, and while many desire a greater voice in how the SAR is run, they are prudent people wary of pushing Beijing too far. Residents are wary of provoking a political backlash from Beijing or inviting economic fallout in the territory. That said, if Hong Kong residents find it increasingly difficult or dangerous to make their voices heard, they may opt to exit the territory, as many did after the Tiananmen Square crackdown and before the handover-an outcome that could cause Hong Kong to lose valuable human capital (a "brain drain"). ${ }^{38}$ This 


\section{The likelihood of future social disaffection in Hong Kong also raises a policy challenge for the United States.}

development would undermine business confidence in the territory and would not bode well for China's policy toward Taiwan.

The likelihood of future social disaffection in Hong Kong also raises a policy challenge for the United States: What is the best way to stand up for American values and promote U.S. national interests? Given Beijing's paranoia about the threat of foreign subversion, Washington should exercise prudence when proffering moral or material support for individuals and organizations in Hong
Kong. While the United States should not shy away from public expressions of concern for human rights and freedoms, Washington should be aware that Beijing is likely to interpret any support for prodemocracy organizations in the territory as part of an organized attempt to subvert the CCP regime.

Whatever actions Chinese leaders take, Hong Kong has proven to be remarkably resilient, weathering a series of major shocks across the decades: turmoil in China, stock market crashes, regional and global financial crises, typhoons, riots, and the transfer of sovereignty from London to Beijing. Therefore, there are good reasons to think that the pragmatic, savvy, and diligent people of Hong Kong will continue to cope and prosper. 


\section{Notes}

${ }^{1}$ According to the Heritage Foundation's Freedom Index. See "Index of Economic Freedom," Heritage Foundation website, undated. As of November 3, 2016: http://www.heritage.org/index

But Hong Kong does possess significant barriers to competition in such markets as housing, construction, and taxis. See, for example, Richard Wong, "Hong Kong Is the King of Crony Capitalism and That Should Be a Worry for the Competition Commission," South China Morning Post, June 7, 2016. As of November 3, 2016: http://www.scmp.com/business/article/1967952/

hong-kong-king-crony-capitalism-and-should-be-worry-competition-commission

${ }^{2}$ Bruce Bueno de Mesquita, David Newman, and Alvin Rabushka, Red Flag Over Hong Kong, Chatham, N.J.: Chatham House, 1996, p. 119. The study asserted "[a] great cloud of uncertainty hangs over Hong Kong" (p. 33).

${ }^{3}$ See, for example, Teddy Ng and Peter So, "Hong Kong Added to Beijing's List of 'Core interests' Amid Post-Occupy Unease," South China Morning Post, January 29, 2015. As of November 3, 2016:

http://www.scmp.com/news/china/article/1694486/hong-kong-added-beijingslist-core-interests-amid-post-occupy-unease

See, also, Michael D. Swaine, "China’s Assertive Behavior: Part One: Core Interests," China Leadership Monitor, No. 34, Winter 2011, p. 7. As of November 3, 2016:

http://www.hoover.org/research/chinas-assertive-behavior-part-one-core-interests

${ }^{4}$ Kevin Honglin Zhang, "Why Does So Much FDI from Hong Kong and Taiwan Go to Mainland China?" China Economic Review, Vol. 16, No. 3, September 2005, pp. 293-307.

${ }^{5}$ Yun-Wing Sung, "The Hong Kong Economy Through the 1997 Barrier," Asian Survey, Vol. 37, No. 8, August 1997, p. 711.

${ }^{6}$ See, for example, Andrew Scobell, "Hong Kong's Influence on China: The Tail that Wags the Dog?” Asian Survey, Vol. 27, No. 6, June 1988, pp. 599-612.

${ }^{7}$ Norman T. L. Chan, "RMB Internationalisation Hong Kong: The Bridge Linking China with the Rest of the World," Hong Kong Monetary Authority, September 16, 2015. As of November 3, 2016:

http://www.hkma.gov.hk/eng/key-information/speech-speakers/ ntlchan/20150916-1.shtml

${ }^{8}$ Yuqing Xing and Manisha Pradhananga, "How Important Are Exports and Foreign Direct Investment for Economic Growth in the People's Republic of China?" Tokyo: Asian Development Bank Institute working paper 427, 2013. Some of these funds are "round-tripped," meaning it is Chinese money re-entering the mainland from Hong Kong masquerading as FDI so that domestic investors could benefit from tax breaks and avoid the scrutiny of PRC authorities.

9 "Economic and Trade Information on China," Hong Kong Trade Development Council, October 19, 2016. As of November 3, 2016:

http://china-trade-research.hktdc.com/business-news/article/Fast-Facts/ Economic-and-Trade-Information-on-China/ff/en/1/1X000000/1X09PHBA.htm

${ }^{10}$ Cheng Hsiao, H. Steve Ching, and Shui Ki Wan, "A Panel Data Approach For Program Evaluation: Measuring the Benefits of Political And Economic Integration of Hong Kong with Mainland China," Journal of Applied Econometrics, Vol. 27, No. 5, January 2012, pp. 705-740, 708.

${ }^{11}$ But this decline is also because of the effect of an extensive anticorruption campaign on the mainland. Moreover, the decline is possibly also related to the reality that many mainland sojourners do not feel welcome in Hong Kong. SAR residents tend to see mainlanders as interlopers and blame them for a wide array of local problems. For statistics, see "Research and Statistics," Hong Kong Tourism Board, updated November 2016. As of November 3, 2016:

http://partnernet.hktb.com/tc/research_statistics/index.html

${ }^{12}$ While the PRC-backed Chinese Patriotic Catholic Association operates legally on the mainland, it functions independent of the Vatican and has no official ties to the Holy See.

${ }^{13}$ Macao is a former Portuguese colony, which became an SAR of the PRC in 1999, two years after the Hong Kong handover.

${ }^{14}$ The Lee Bo case was especially shocking because he was seized directly from Hong Kong. See, for example, "Publish and Be Abducted?" The Economist, January 9,2016 , pp. 35-36.

${ }^{15}$ Richard C. Bush, "Hong Kong Government Announces Electoral Reform Details," Brookings Institution website, April 23, 2015. As of November 3, 2016: http://www.brookings.edu/blogs/up-front/ posts/2015/04/23-hong-kong-electoral-reform-details-bush

${ }^{16}$ The "Occupy Central with Peace and Love," led by three middle-aged intellectuals, also fed into the broader Umbrella Movement. For more details on the remarkable episode and the relationship between the two groups, see Victoria Tinbur Hui, "Hong Kong's Umbrella Movement: The Protests and Beyond," Journal of Democracy, Vol. 25, No. 2, April 2015, pp. 111-121.

${ }^{17}$ The actual vote was 28 opposed and seven in favor. See, for example, "A Snub for the Party," The Economist, June 20, 2015, pp. 45-46. 
${ }^{18}$ See, for example, "A Snub for the Party," 2015. The "pocket it for now" movement has been low-key, and its origins are ambiguous. It may owe its genesis to tacit encouragement from the Hong Kong establishment.

${ }^{19}$ See, for example, "Disapproval of Leung Reaches a Record High; and Chief Executive Is Failing to Arrest a Popularity Decline, the Latest Poll Shows," South China Morning Post, February 15, 2013, p. 1.

${ }^{20}$ Younger Hong Kong residents tend to support more active displays of dissent than older generations. See, for example, Chris Buckley and Alan Wong, "Hong Kong Students Boycott Classes in Democracy Fight," New York Times, September 23,2014

${ }^{21}$ Michael E. DeGolyer and Janet Lee Scott, "The Myth of Political Apathy in Hong Kong," Annals of the American Academy of Political and Social Science, Vol. 547, September 1996, pp. 68-78.

${ }^{22}$ For a pioneering study of Hong Kong political attitudes, see Lau Siu-kai and Kuan Hsin-chi, The Ethos of the Hong Kong Chinese, Hong Kong: Chinese University of Hong Kong, 1988. But Hong Kong (and Taiwan) residents embrace multiple identities - both distinct to Hong Kong (and Taiwan) as well as a broader pan-Chinese identity. See, for example, Frank C. S. Liu and Francis L. F. Lee, "Country, National, and Pan-National Identification in Taiwan and Hong Kong: Standing Together as Chinese?" Asian Survey, Vol. 53, No. 6, November/December 2013, pp. 1112-1134.

${ }^{23}$ See, for example, Neil Gough, "Hong Kong Wealth Gap on Display in Protests," New York Times, October 6, 2014.

${ }^{24}$ Michael Forsythe and Alan Wong, "Vote in Hong Kong Deepens a Thorn in China's Side,” New York Times, September 5, 2016.

${ }^{25}$ For views on the Hong Kong situation expressed by PRC President Xi Jinping, see Edward Wong, "In New China, 'Hostile' West Is Still Derided," New York Times, November 12, 2014, and Mark Landler, "Fruitful Visit by Obama Ends with a Lecture from Xi,” New York Times, November 13, 2014.

${ }^{26}$ The fish ball riots also reflect poorly on the judgement of the Hong Kong government, specifically on how it chose to enforce laws against illegal street food vendors. Nevertheless, it is difficult to generalize from this episode, since it was a special case involving Mongkok neighborhood triads (organized criminal gangs).

For an overview and analysis of the episode, see "The Significance of Hong Kong's Fish Ball Riots," Stratfor, February 12, 2016. As of November 3, 2016: https://www.stratfor.com/analysis/significance-hong-kongs-fish-ball-riots

27 "Occupy Coincides with Mainland Tourist Drop, Golden Week HK Retail Sales Drop Massively by 40\%," South China Morning Post, October 7, 2014. As of
November 3, 2016:

http://www.nanzao.com/tc/business/14c3166f452663a/

zhan-ling-pian-feng-lu-ke-jian-huang-jin-zhou-gang-ling-shou-da-die-si-cheng

${ }^{28}$ Government of the Hong Kong Special Administrative Region, “Third Quarter Economic Report 2014,” November 2014. As of February 2, 2016: http://www.hkeconomy.gov.hk/en/pdf/er_14q3.pdf

${ }^{29}$ This is what occurred in 1982 when China first indicated its intention to assume sovereignty over Hong Kong. This news triggered a crisis of business confidence. See, for example, William H. Overholt, "Hong Kong and the Crisis of Sovereignty," Asian Survey, Vol. 24, No. 4, April 1984, pp. 472-473.

${ }^{30}$ For a history of democratic development in Hong Kong, see Suzanne Pepper, Keeping Democracy at Bay: Hong Kong and the Challenge of Chinese Political Reform, New York: Rowman and Littlefield, 2008.

${ }^{31}$ See Norman Miners, The Government and Politics of Hong Kong, 5th ed., Hong Kong: Oxford University Press, 1995.

${ }^{32}$ Larry J. Diamond, “Thinking About Hybrid Regimes," Journal of Democracy, Vol. 13, No. 2, April 2002, pp. 21-35.

${ }^{33}$ See James Pomfret, "In HK, China Likely to Use Pressure, Intimidation to Ward Off More Protests,” Reuters, December 12, 2014. As of January 18, 2016 : http://www.reuters.com/article/us-hongkong-china-campaign-

idUSKBN0JQ0W720141212

James Pomfret, "Hong Kong University Faces Pressure from Pro-Beijing Opponents of Liberal Scholar," Reuters, September 29, 2015. As of January 18, 2016: http://www.reuters.com/article/hongkong-university-idUSL3N11Z2TV20150929 James Pomfret and Rain Liang, "Missing Hong Kong Publisher Returned to China 'Voluntarily'-Wife," Reuters, January 5, 2016. As of January 18, 2016: http://uk.reuters.com/article/uk-hongkong-publisher-idUKKBN0UJ13820160105.

${ }^{34}$ There have been exceptions, however. On July 4, 2015, the PLA garrison conducted exercises in the New Territories, in the Tuen Mun/Castle Peak area. This was also the first time that the exercises were open to the public, with some 500 Hong Kong residents invited to observe. See "PLA Hong Kong Garrison Opens Joint Exercises to Public for First Time,” BBC Chinese, July 4, 2015. As of November 3, 2016:

http:/www.bbc.com/zhongwen/trad/china/2015/07/

150704_hongkong_pla_garrison_drill

On the term invisible army, see Andrew Scobell, "China's Evolving Civil-Military Relations: Creeping Guojiahua," Armed Forces and Society, Vol. 31, No. 2, Winter 2005, pp. 227-244. 
${ }^{35}$ In 2014, some scuffles between police and protestors occurred and one illconceived incident involving teargas has slightly tarnished the image of a force that is justly proud of its reputation as "Asia’s finest." Then, in February 2016, significant rioting occurred in Mongkok when hundreds of rioters-many who were probably gangsters - attacked police with bricks, bottles, and other weapons. The police responded with batons and pepper spray, and fired two warning shots into the air. Approximately 90 police were injured and some 50 people were arrested. No civilians were shot or severely injured and there were no fatalities. See "The Significance of Hong Kong's Fish Ball Riots," 2016.

${ }^{36}$ Remarkably, Hong Kong independence has considerable public support, especially among young people. See Gene Lin, "CUHK Survey Finds Nearly $40 \%$ of Young Hongkongers Want Independence After 2047," Hong Kong Free Press, July 25, 2016. As of November 3, 2016:

https://www.hongkongfp.com/2016/07/25/17-hongkongers-supportindependence-2047-especially-youth-cuhk-survery/
${ }^{37}$ On the number of U.S. residents and companies in Hong Kong, see Bureau of East Asian and Pacific Affairs, "U.S. Relations with Hong Kong: Fact Sheet," February 25, 2016. As of November 3, 2016:

http://www.state.gov/r/pa/ei/bgn/2747.htm

For two-way trade figures, see "Foreign Trade: 2014: U.S. Trade in Goods with Hong Kong," U.S. Census, 2014. As of November 3, 2016:

http://www.census.gov/foreign-trade/balance/c5820.html\#2014

On the amount of FDI, see "Hong Kong," Office of the United States Trade Representative, undated. As of November 3, 2016:

https:/ustr.gov/countries-regions/china-mongolia-taiwan/hong-kong

${ }^{38}$ See Elaine Yau, "As More Residents Leave Hong Kong, Experts Worry About a Brain Drain," South China Morning Post, September 2, 2013. As of November 3 , 2016:

http://www.scmp.com/lifestyle/family-education/article/1300687/

more-residents-leave-hong-kong-experts-worry-about-brain 


\section{About This Perspective}

This Perspective considers the future trajectory of the Special Administrative Region in light of the 2014 prodemocracy street protests and their aftermath. First, it examines economic and political trends in Hong Kong-China relations; second, it considers the issues triggering these protests; third, it considers the effect of the protests; fourth, it explores possible future scenarios; and lastly, it offers some concluding observations.

This study was made possible by a generous gift from the Cyrus Chung Ying Tang Foundation. Through this gift, the RAND Center for Asia Pacific Policy established the Tang Institute for U.S.-China Relations in 2007, within which this research was conducted.

The RAND Center for Asia Pacific Policy (CAPP) is part of International Programs at the RAND Corporation. CAPP provides analysis on political, social, economic, and technological developments in and around the Asia Pacific. Through research and analysis, CAPP helps public and private decisionmakers solve problems, tackle challenges, and identify ways to make society safer, smarter, and more prosperous. For more information on the RAND Center for Asia Pacific Policy, see www.rand.org/international_ programs/capp or contact the director (contact information is provided on the web page).

\section{About the Authors}

Andrew Scobell is a senior political scientist at the RAND Corporation.

Min Gong is an economist and behavior scientist at the RAND Corporation.

\section{Limited Print and Electronic Distribution Rights}

This document and trademark(s) contained herein are protected by law. This representation of RAND intellectual property is provided for noncommercial use only. Unauthorized posting of this publication online is prohibited. Permission is given to duplicate this document for personal use only, as long as it is unaltered and complete. Permission is required from RAND to reproduce, or reuse in another form, any of our research documents for commercial use. For information on reprint and linking permissions, please visit www.rand.org/pubs/permissions.html.

The RAND Corporation is a research organization that develops solutions to public policy challenges to help make communities throughout the world safer and more secure, healthier and more prosperous. RAND is nonprofit, nonpartisan, and committed to the public interest.

RAND's publications do not necessarily reflect the opinions of its research clients and sponsors. RAND ${ }^{\circledR}$ is a registered trademark.

For more information on this publication, visit www.rand.org/t/PE203.

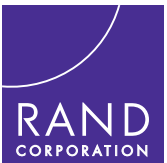

www.rand.org 